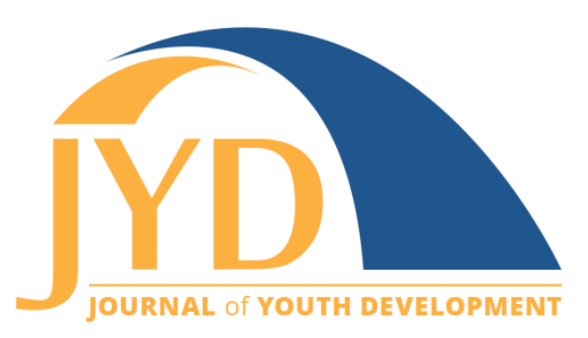

http://jyd. pitt. edu/ | Vol. 14 Issue 2 DOI 10.5195/jyd.2019.682 | ISSN 2325-4017 (online)

\title{
A Content Analysis of the Contributions in the Narratives of DACA Youth
}

\section{Darlene Xiomara Rodriguez}

Kennesaw State University, Department of Social Work and Human Services

drodri30@kennesaw.edu

\section{Sanjuana C. Rodriguez}

Kennesaw State University, Department of Elementary and Early Childhood srodri51@kennesaw.edu

\section{Banti C. V. Zehyoue}

Kennesaw State University, Department of International Conflict Management bzehyoue@students.kennesaw.edu

\begin{abstract}
This study utilized cultural community wealth (Yosso, 2005) to explore the ways in which Deferred Action for Childhood Arrivals (DACA) youth make use of social media. Through the use of content analysis (Hay, 2005), the authors analyzed social media interviews publicly posted by DACA youth. Findings reveal that $D A C A$ youth engage in social media as a form of activism and to mobilize their communities. The findings support and extend our understanding of the ways that DACA youth are an asset to the wider community. Implications for those working with DACA youth are provided.
\end{abstract}

Key words: DACA, content analysis, social media, activism, cultural community wealth

\section{Introduction}

In the year 2015, there were about 12 million undocumented immigrants who lived in the United States (Baker, 2018). Within this population of undocumented immigrants, about one million were 18 years or younger (Baker, 2018). Most of these individuals were brought to the United States as minors by their parents and therefore not aware of their unlawful entry into the United States. Many of these minors find out that they are undocumented when they are

(c) EY New articles in this journal are licensed under a Creative Commons Attribution 4.0 License. This journal is published by the University Library System, University of Pittsburgh and is cosponsored by the University of Pittsburgh Press. The Journal of Youth Development is the official peer-reviewed publication of the National Association of Extension 4-H Agents and the National AfterSchool Association. 
Content Analysis of DACA Youth Narratives

ready to get a driver's license or when they are planning to attend college. Having this status of undocumented living in the United States can have negative developmental, economic, and psychological effects on individuals (Gonzales, Suárez-Orozco, \& Dedios-Sanguineti, 2013; Suárez-Orozco, Yoshikawa, Teranishi, \& Suárez-Orozco, 2011). An individual's immigration status can also impact educational decisions that are made, such as decisions related to graduating from high school or entering a post-secondary institution (McWhirter, Ramos, \& Medina, 2013). Despite these challenges, these young people have a wealth of potential capital to offer society and this capital is being underutilized due to the restrictive policies in which these youth must operate.

\section{Challenges Faced by DACA Youth}

DACA youth have faced many obstacles including many shortcomings of legislation that has attempted to provide a pathway for legalization. Various versions of the Development Relief and Education for Alien Minors Act, more commonly known as the DREAM Act, have been introduced into the U.S. Congress every year since 2001, but all of these versions have failed to pass. In 2010, when the DREAM Act was reintroduced, although the legislation garnered the more congressional and public support than previous versions, it failed to pass (Pérez, 2012). In 2012, President Barack Obama issued an executive order known as Deferred Action for Childhood Arrivals (DACA) that prevented youth who meet certain qualifications from being deported and provided them the opportunity to obtain a work permit. To be eligible for these DACA protections, among other restrictions, applicants had to be under the age of 31 at the time of submitting their application and to have been 16 years or younger when they arrived in the United States (Department of Homeland Security [DHS], n.d.). Under DACA, individuals are eligible for a reprieve in deportation (although there have been cases where individuals have been deported), but they are not eligible for a permanent residence and therefore cannot become citizens (DHS, 2016).

Another barrier faced by DACA youth are the financial obstacles to obtaining a higher education (Núñez, 2014). The 1996 Illegal Immigration Reform and Immigrant Responsibility Act (IIRIRA) and the Personal Responsibility and Work Opportunity Reconciliation Act made it more difficult for individuals to be eligible for any federal assistance, including federal financial aid. Although undocumented students have protection for a K-12 education under the landmark 1982 Plyler $v$. Doe U.S. Supreme court decision, they are not afforded these same benefits after graduating from high school. In fact, the IIRIRA states the following in regard to a secondary education: 
Content Analysis of DACA Youth Narratives

... an alien who is not lawfully present in the United States shall

not be eligible on the basis of residence within a State (or a

political subdivision) for any postsecondary education benefit

unless a citizen or national of the United States is eligible for such

a benefit (in no less an amount, duration, and scope) without

regard to whether the citizen or national is such a resident

(Section 507.a).

Although at least 18 states have approved provisions for in-state tuition for DACA, there are at least three states (Arizona, Georgia, and Indiana) that do not allow DACA students to receive in-state tuition, and two states (Alabama and South Carolina) ban DACA students from enrolling in any public institution of higher education (Hultin, 2015). These restrictions make it difficult for DACA youth to obtain a post-secondary education.

One of the most pressing issues that DACA youth face is the issue of uncertainty (SuarezOrozco et al., 2015). On September 5, 2017, the U.S. Citizenship and Immigration Services issued a memorandum that rescinded the June 2012 memorandum that created DACA (DHS, n.d.). The decision to rescind DACA is currently being disputed in federal courts and DACA recipients are currently still able to renew their DACA status (DHS, n.d.), but no new applications are being accepted. Although the DACA status has not been removed, this has left youth with a sense of uncertainty because they are unsure of how the cases will play out in federal courts or what steps congress will take to protect or expose DACA recipients.

\section{Theoretical Background}

For this study we relied on the concept of "cultural wealth" developed by Octavio Villalpando and Daniel Solórzano (2005). This framework rejects notions that students of color-for the purpose of this study-DACA recipients, do not have anything to contribute and are not an asset to the institutions in which they reside. In this work, Villalpando and Solórzano argued that "cultural wealth identifies individual indicators of capital that have rarely been acknowledged and used as assets in examining the cultural and social characteristics of populations of color" (p. 18). The concept of cultural wealth was also adopted and further developed by Yosso (2005) as she outlined the six forms of community cultural wealth that exist within communities of color. 
Content Analysis of DACA Youth Narratives

1. Aspirational capital refers to an individual's "ability to maintain hopes and dreams for the future" ( $p$. 77). This capital points to individual's ability to see oneself beyond the barriers or circumstances that exist.

2. Linguistic capital includes the "intellectual and social skills attained through communication experiences" (p. 78). In particular, Yosso (2005) points to the asset of bilingualism and discusses how individuals are able to draw upon the resources of speaking and/or reading and writing in multiple languages.

3. Familial capital refers to cultural understandings and benefits of kinship. This form of capital involves more than just immediate family and includes those who individuals may consider family.

4. Social capital refers to the "networks of people and community resources" (p. 79). These networks can serve as a resource for individuals in different ways, including in attaining an education and gaining employment.

5. Navigational capital refers to an individual's ability to navigate social institutions. Particularly, "it infers the ability to maneuver through institutions not created with communities of color in mind" (p. 80).

6. Resistant capital refers to knowledge and skills that are fostered that resist and challenge inequalities.

This framework was adopted in order to position DACA recipients as having multiple strengths and contributing to the communities in which they reside. This challenges the dominant narrative that positions DACA youth as deficits to their communities. In contrast, we used Yosso's concept of cultural wealth to "shift[s] the research lens away from a deficit view of Communities of Color as places full of cultural poverty and disadvantages, and instead focus[es] on and learn[s] from these communities' cultural assets and wealth" (p. 82). Thus, our goal is to offer a counternarrative and discuss findings that point to DACA youth as having rich cultural wealth.

\section{Purpose}

The purpose of this study was to analyze social media narratives that DACA youth have posted online on social media platforms in order to study the strengths and contributions of this group. These social media platforms included Facebook and YouTube. In particular, we focused on how DACA youth use social media as a means to engage in activism and to mobilize their communities. We posed the following research questions for this study:

1. How have DACA youth used social media as a means to engage in activism? 
Content Analysis of DACA Youth Narratives

2. How have DACA youth used social media to counter established narratives?

\section{Methodology}

To answer the first question, we examined media, specifically videos posted on social media, that have been used in the broader context of immigration mobilization. These social media platforms included Facebook, YouTube, and recorded news media interviews. The narratives were included on pages created by DACA recipients or organizations that support these youth. We also searched for these narratives using terms such as "DACA recipient interviews," "DACA recipients," and "DACA videos." We specifically looked for videos that included DACA recipients describing their experiences. As such in the next section, we consider how social media has been used to create narratives that counter established power structures with the aim of changing legal and public opinion. To answer the second question, we examine the emergence of DACA youth utilizing social media during a critical period of policy making through the theoretical lens of community cultural wealth (Yosso, 2005).

To do this, we conducted content analysis (Hay, 2005) of primary documents and relevant media discourse regarding the policy and the people affected by DACA. Media content analysis has been used widely as a method in a variety of disciplines to explore discourse on particular topics, including immigration (Dragojevic, Sink, \& Mastro, 2017; Mastro, Tukachinsky, BehmMorawitz, \& Blecha, 2014; May et al., 2015; Saraisky 2015; Williams, 2016). Other research has examined DACA as a policy and the implications for the DACA community from other perspectives and through different methods.

First, primary documents collected from the USCIS website were analyzed to understand the evolution of the policy as well as its termination. These documents include web pages and documents posted to the website. Second, a database of social media content was constructed of DACA youth between September 2017 and March 2018. This time frame was selected as it captures the time of termination notification and when the executive order officially expired. By searching for articles with the term "DACA," we collected 50 interviews of DACA individuals that were posted on social media via online news source databases. Each interview was transcribed and then analyzed for a priori themes related to components of our research questions and for emergent organic themes. Once the videos were transcribed, two of the researchers coded the transcripts of the videos individually. The researchers then conducted inter-rater reliability checks when coding the transcripts of the interviews. 
Content Analysis of DACA Youth Narratives

We coded for specific a priori themes related to the cultural community wealth (Yosso, 2005) framework. These a priori themes included the different types of capital identified by Yosso: aspirational, familial, linguistic, social, navigational, and resistant. The content analysis was also mindful of any organic themes that emerged beyond the specific a priori themes. Of the a priori themes two stood out the most through our content analysis process: DACA youth and their role in activism and engagement (Gonzales \& Terriquez, 2013; Pérez et al., 2010; Salas, Preciado \& Torres, 2016) and how DACA youth individuals are inspired by prior social movements to mobilize their communities (Hope, Keels, \& Durkee, 2016). As such, we will focus on discussing those two themes in the next section.

\section{Data Analysis and Findings}

Once the coding of the interviews was complete, the codes were sorted into categories based on how they were related. In examining and organizing the codes into themes for analysis, it became apparent that there were two prominent themes found in the data. These themes centered on the heightened level of activism and engagement by DACA youth and how they utilized and referenced social movements to mobilize their communities. Recognizing that these students have attended and been instructed by U.S. educators in a U.S. educational system, the irony is that they are utilizing what they learned in the formal classroom to change public opinion. Below we unpack each of the themes that developed from the data.

\section{DACA Youth Activism and Engagement}

DACA recipients whose interviews were analyzed for this study keep up their resolve by participating in activism, social movements, and community engagement initiatives in which they educate each other and others about DACA. In the passing of DACA, a new type of movement was brought to life as expressed by one participant who described DACA as the "victory of the immigration youth movement." These youth use their stories to promote the positive contributions they are making to society. They are keen to have their plight remain in the media and ensure that others are aware of who they are and the larger immigrant populations' struggles and obstacles. One young person expressed that until this issue is resolved, "I'm not going down without a fight."

Engagement is key in the DACA movement, even when individuals whose interviews were part of the study were safe from deportation or got an opportunity to change their immigration status from undocumented to a legal status, they stayed engaged in the process by advocating 
Content Analysis of DACA Youth Narratives

for others who still rely on DACA protections. These individuals continue "advocating for the rights of undocumented people" and keep others engaged in the process as "freedom fighters" and asking for others to join in the fight. Many of the DACA recipients in this study take on the role of advocate and encourage others to use this "time to fight back, to reclaim the joy of our communities, and reclaim the joy of what it means to come together to fight for something that we really do believe." They want to be heard, and expressed a desire for those in their community to know who they are.

In this study, DACA recipients also advocated for themselves in order to change the media's portrayal of them. DACA youth challenged the narrative and offered a counterstory to the negative narrative often associated with immigrants. They also attempted to impact change in their own way: "I feel that we were not very disruptive. We were just making a statement and I think, I know that some people got arrested but I don't think that they should have been." DACA youth in the study understood that there were consequences to their activism, but as one participant stated, "I have come to terms with the possibility of being deported and what my activism means. I'm OK with that." These statements demonstrate the commitment that DACA youth have to sharing their stories in order to enact change. In essence, many are willing to risk an arrest if it means that they are making a difference. The issue of raising awareness was key for the DACA recipients in the study and that was their way of humanizing themselves because they are at such a power disadvantage in communities.

Some DACA recipients that were afraid to speak out found their voice in the activism of their peers when they attended college. Institutions of higher education have long been a welcoming training ground for activism; this was no different for DACA youth in this study, as reported by this participant:

Community college is where I found this desire to organize and to fight and advocate for tuition equity for undocumented students. I graduated and went to UCLA, I continued that activism but really [ramped] it up and starting lobbying at the state level.

Others stated that their activism was liberating.

Throughout my college experience I've had the privilege to witness some of the most incredible formations and continuations of social movements. Now while all these movements are different in scope and in subject, one thing they have in common is that they're rooted in elements of empowerment and acceptance. 
Institutions of higher education have traditionally provided a space in which these social movements can flourish. DACA youth whose interviews were studied found solidarity in other students and are able to learn about advocacy work in this space. Some learned about advocacy through their work experiences, others learned about activism through their connections with civic organizations or in events that provided "legal consultation for immigrants." This finding is related to the social capital that individuals are able to draw upon when they are able to rely on extended networks for support in doing advocacy work.

Yet, others had different experiences. There were DACA recipients in the study that did not find that the communities that they lived in prepared them to do advocacy work in the educational institutions. Some youth expressed how family systems as opposed to community systems provided that support. This type of capital is what Yosso (2005) refers to as familial capital. Some of the DACA recipients remarked on how members of their family in their home country were active and involved, and that although they were now in the United States, that desire to aid other marginalized groups and advocate for themselves did not waiver. One participant recalled, "My mom has been active even when she was in Mexico . . . [She] used to take [me] to marches."

Some DACA recipients shared how they aspired to help others due to their own experiences as DACA beneficiaries. Because of the benefits offered through DACA, some of them were able to establish professional careers. These professions include doctors, lawyers, accountants, and therapists and they are using their professional training to aid others. Additionally, these youth are making significant contributions through their professional skills to their communities and society as a whole. For example, in the study we found that there are immigration attorneys who are not only DACA recipients, but who also aid clients who seek to obtain and retain their DACA status. Many still aspire to join the legal profession and do the same:

There are lawyers that work [here] who use to be and are still undocumented who are working with these clients directly. We could be the lawyer, we could be the advocates as well. We don't just have to be the clients.

This work allows the DACA beneficiaries to be both providers and recipients of services. Through the interviews we found that DACA youth often look to one another as a source of inspiration to continue to do the activism work as well as the everyday work of helping others. One of findings from the interviews is that DACA youth often unite through helping others and 
Content Analysis of DACA Youth Narratives

they use chants to remind others that they have something to contribute. Thus, as the DACA drama lingers unresolved, DACA recipients want the world to know the following: "Everywhere we go, people want to know, who we are, so we tell them, we are the dreamers' the mighty, mighty dreamers." This chant has been sung and heard by many who seek to mobilize their communities. Although the cause or community may differ, the aim remains the same: social movement and mobilization of their communities as a natural outgrowth of their personal civic engagement and advocacy efforts.

\section{Inspired by Social Movements, DACA Youth Mobilize Their Communities}

Social movements are occurring all across the country, and the DACA youth continue to be active in these social movements. DACA youth are using their energy to mobilize the community of their supporters so that people can have a better understanding of their situation, understand their circumstances, and advocate on their behalf. Support systems are a crucial part of one's life, whether or not these systems are blood relatives or close friends, having people to lean on or engaging with people who share similar experiences can lend strength in the midst of chaos and uncertainty. This is the case for DACA youth.

This sense of belonging is fostered not only by each other, but by the faculty, staff, and administrators who interact with these students on a daily basis. Historically, teachers have played a huge role in the lives of students, and the teachers of DACA students are no different. DACA youth shared that having a teacher who was supportive and empathetic to the student's life circumstances impacted their learning in the classroom and impacted their lives. A student recounted a teacher's retelling of a story:

It mattered to me that [Juan] was hard working, he was enthusiastic. He was always coming to class. It's our job to educate them, to make them better citizens of the world. It doesn't matter what country they're from or what their background or their legal papers are.

This same DACA recipient spoke about a positive memory regarding this very teacher and how it influenced his own educational journey:

Mrs. Daniel was the very first member of my personal underground railroad-Americans who decided to help undocumented immigrants like me. Other members of my underground railroad include my high school superintendent and 
Content Analysis of DACA Youth Narratives

my high school principal. For more than a decade now, [these two people] have been with me every step of the way, guiding me and supporting me as I try to define to me what it means to be an American.

This support system does not end when the students graduate from high school, but it is fostered when students enter into college by faculty and staff at those institutions. In doing this, the students draw from navigational capital (Yosso, 2005) that is gained from having the guidance and support of educators. One of the DACA students indicated how, upon entering college, she was greeted and welcomed by a group of other undocumented students at her institution. She stated the following about how the students felt "united as one with the help of faculty and staff." This sense of belonging helped this student persist in her academic studies because of people and allies who simply understood the challenges that she faced. And even though their support did not change her immigration status, she was able to lean on them for help.

Just as classmates have been a great support system, so have college professors and other educators who have dedicated some time to the issue of the undocumented. In the study, we found that DACA youth understood that educators had played an important role in aiding students. One student recalled how her interactions with an educator helped her, "my identity as an American Korean was nurtured and affirmed, I was allowed to be both for the first time in my life." This is a powerful sentiment of the importance of educators' valuing and validating the experiences of their students regardless of the differences that they bring into the classroom.

Local communities have also played an important role in the fight to get permanent status for the undocumented. DACA youth shared how seeing others in their community standing with a group facing injustice renewed their spirit to fight. DACA youth expressed a sense of gratitude for those who stood with them, "I'm really grateful for all the people who supported me and for the Dreamers as well. Thank you." DACA youth shared how members of the community who were often on the front lines were their employers. For employers who have DACA youth employees, they see first-hand the implications of obtaining legalized status or the removal of their temporary protections to not only the bottom line, but their company's morale. However, they too often feel disempowered or ignorant on what to do to "fix things" or help their employees "get right with immigration." 
Content Analysis of DACA Youth Narratives

Maintaining legal employment can be challenging for someone with an undocumented status, but some have private employers who have assured them that they will be able to maintain their employment. A posture of wait and see seems to be what private employers are taking: "Don't worry about it, we will worry about it when it gets here." But "here" is front and center due to the entangled system where employers are mandated to "report" or not employ without a series of documents. These employers are continuing to employ DACA youth despite the risk that they may someday lose their work permits. This type of arrangement is a rare act of kindness and support. One DACA recipient recounted his employer's description of hiring him:

I looked at him and said, "Listen, this is a really hard job." He said, "I'm willing to work." I asked, "You willing to work real hard?" He said, "I'm willing to work real hard. "And I said, "OK, go to work. "And it was that simple.

Employers are key for DACA youth to continue to thrive and individuals shared how employers were a source of not just work, but also encouragement to continue to fight to maintain their work permits or to change legislation to obtain a permanent resident status.

Although many members of the DACA community have the support of their teachers, school administrators, employers, and others in their communities, they also often provide support for each other. But in doing so, they put themselves in a precarious situation: stepping out of the "protective" shadows to cast a light on how they and others are being impacted. "I'm fighting for my family; I'm standing for the friends of mine that can't even stand because they are scared." Others are standing up for their rights and feel reconciled to act regardless of the consequences. One person noted "I have come to terms with the possibility of being deported and what my activism means. I'm OK with that." Another DACA young adult stated, "What's giving me strength right now is that we are kind of unified." As stated previously, their message is clear in spite of the questions and challenges that lie ahead; they are committed and "they will stand together and fight." In engaging in this type of activism for each other, the DACA youth are helping to foster both familial and social capital (Yosso, 2005) within other DACA youth and thus countering narratives that DACA youth do not contribute to their communities.

When asked why they continue to expose themselves and risk being arrested for rallying and marching and creating this social movement, the overwhelming response is, "We need to continue mobilizing and coming together to bring about changes that will benefit all of our immigrant community members and [result in] a permanent solution." 


\section{Discussion}

The dominant narrative for undocumented students still focuses on the negative characteristics of DACA individuals. Our focus for this study was the contributions of DACA youth. We explored how social media and new technologies that allow individuals to communicate easily have provided a vehicle for DACA youth to engage in activism and mobilize their communities by sharing their experiences with others. Social media has become a way in which youth can disseminate powerful videos and messages, "The fractured and permeable world of social media provides these youths with ample opportunities to join the movement and assume important roles within it" (Nicholls \& Fiorito, 2015, p. 91). Results from this study are consistent with other studies that have found that Black and Latino youth are politically engaged (Hope et al., 2016; Watts, Diemer, \& Voight, 2011) and that their background and previous experiences are an impetus for "advocacy and action that seek to improve sociopolitical conditions for racial/ethnic minorities in the United States" (Hope et al., 2016, p. 212).

This study also highlights how DACA youth shared ways in which they were able to use the different types of capital. DACA youth shared the different types of community cultural wealth (Yosso, 2005) that enabled them to engage in this kind of work. In particular, DACA youth discussed how they made use of social capital as they drew upon their social networks.

Admittedly, however, there are limitations to our study. This study is a first step in identifying the assets and contributions of DACA students, particularly as related to the activism work that they engage in through the use of social media. Our analysis relied on data that was publicly available via social media platforms; this limits the generalizability of our findings because we can speak to the experiences of only the DACA youth who made their stories available through social media platforms. Despite this limitation, the results of our study are important because they help us to further understand the challenges that are faced by DACA youth as well as the activism work that they engage in.

\section{Conclusions}

DACA youth are findings ways to share their own powerful stories and to engage in work that supports each other. This study highlights some of the contributions that DACA students make, particularly in regard to how they have used social media for activism and to mobilize their community. An implication for organizations working with DACA youth is to understand that they are capable of contributing to organizations in different ways. In this study, DACA youth 
shared how they felt a sense of responsibility to share the social capital with other DACA youth. While recognizing the contributions of DACA youth is important, it is equally important for organizations to find ways to support DACA youth. While the dialogue continues among DACA youth, communities play a role in creating organizations that are inclusive of the diversity of DACA youth and advocate for these youth. While their narratives are those of resistance, the future of DACA youth continues to be that of uncertainty. The risk of deportation continues to be a real threat. It is the responsibility of communities to reframe the role of DACA youth and recognize that these young people have a right to live and thrive in the communities in which they live and to which they contribute. Additionally, this study points to the important role that these youth play in communities. DACA youth have already shown that they contribute to their communities in different ways.

\section{References}

Baker, B. (2018). Estimates of the illegal alien population residing in the United States: January 2015. Retrieved from Department of Homeland Security website: https://www.dhs.gov/sites/default/files/publications/18_1214_PLCY_pops-est-report.pdf

Department of Homeland Security, U.S. Citizenship and Immigration Services. (n.d.). Consideration of deferred action for childhood arrivals. Retrieved from https://www.uscis.gov/archive/consideration-deferred-action-childhood-arrivals-daca

Dragojevic, M., Sink, A., \& Mastro, D. (2017). Evidence of linguistic intergroup bias in US print news coverage of immigration. Journal of Language and Social Psychology, 36(4), 462-472. doi:10.1177/0261927X16666884

Gonzales, R. G., Suárez-Orozco, C., \& Dedios-Sanguineti, M. C. (2013). No place to belong: Contextualizing concepts of mental health among undocumented immigrant youth in the United States. American Behavioral Scientist, 57, 1174-1199. doi:10.1177/0002764213487349

Gonzales, R.G., \& Terriquez, V. (2013). How DACA is impacting the lives of those who are now DACAmented: Preliminary findings from the National UnDACAmented Research Project. Retrieved from American Immigration Council website:

https://www.americanimmigrationcouncil.org/research/how-daca- impacting-lives-those-who-arenow-dacamented

Hay, I. (Ed.) (2005). Qualitative research methods in human geography. Oxford, UK: Oxford University Press.

Hope, E. C., Keels, M., \& Durkee, M. I. (2016). Participation in Black Lives Matter and deferred action for childhood arrivals: Modern activism among Black and Latino college students. Journal of Diversity in Higher Education, 9(3), 203. doi:10.1037/dhe0000032 
Hultin, S. (2015, October 29) Undocumented student tuition: Overview, National Conference of State Legislatures. Retrieved from http://www.ncsl.org/research/education/undocumented-studenttuition-overview.aspx\# .

Mastro, D., Tukachinsky, R., Behm-Morawitz, E., \& Blecha, E. (2014). News coverage of immigration: The influence of exposure to linguistic bias in the news on consumer's racial/ethnic cognitions. Communication Quarterly, 62(2), 135-154. doi:10.1080/01463373.2014.890115

May, S. F., Flores, L. Y., Jeanetta, S., Saunders, L., Valdivia, C., Arévalo Avalos, M. R., \& Martínez, D. (2015). Latina/o immigrant integration in the rural midwest: Host community resident and immigrant perspectives. Journal of Latina/o Psychology, 3(1), 23. doi:10.1037/lat0000029

McWhirter, E. H., Ramos, K., \& Medina, C. (2013). ¿Y ahora qué? Anticipated immigration status barriers and Latina/o high school students' future expectations. Cultural Diversity and Ethnic Minority Psychology, 19(3), 288. doi.org/10.1037/a0031814

Nicholls, W. J., \& Fiorito, T. (2015). Dreamers unbound: Immigrant youth mobilizing. New Labor Forum, 24(1), 86-92. doi:10.1177/1095796014562234

Núñez, A. M. (2014). Employing multilevel intersectionality in educational research: Latino identities, contexts, and college access. Educational Researcher, 43(2), 85-92. doi:10.3102/0013189X14522320

Pérez, W. (2012). Americans by heart: Undocumented Latino students and the promise of higher education. New York, NY: Teachers College Press.

Plyler v. Doe, 457 U.S. 202 (1982).

Salas, K. M., Preciado, H., \& Torres, R. (2016). Deferred action for childhood arrivals (DACA) and student success in higher education. In H.D. Romo \& O. Mogollon-Lopez (Eds.), Mexico migration to the United States: Perspectives from both sides of the border (pp. 140-158). Austin: University of Texas Press.

Saraisky, N. G. (2015). Analyzing public discourse: Using media content analysis to understand the policy process. Current Issues in Comparative Education 18(1), 26-41.

Suárez-Orozco, C., Yoshikawa, H., Teranishi, R. T., \& Suárez-Orozco, M. M. (2011). Growing up in the shadows: The developmental implications of unauthorized status. Harvard Educational Review, 81(3), 438-472. doi:10.17763/haer.81.3.g23×203763783m75

Villalpando, O., \& Solórzano, D. (2005). The role of culture in college preparation programs: A review of the research literature. In Z. B. Corwin, J. Colyar, \& W. G. Tierney (Eds.), Preparing for college: Nine elements of effective outreach (pp. 13-28). Albany: State University of New York Press.

Watts, R. J., Diemer, M. A., \& Voight, A. M. (2011). Critical consciousness: Current status and future directions. In C. A. Flanagan \& B. D. Christens (Eds.), Youth civic development: Work at the cutting edge. New Directions for Child and Adolescent Development, 2011(134), 43-57. doi:10.1002/cd.310 
Journal of Youth Development | http://jyd.pitt.edu/ | Vol. 14 Issue 2 DOI 10.5195/jyd.2019.682 Content Analysis of DACA Youth Narratives

Williams, K. M. (2016). Black political interests on immigrant rights: Evidence from Black newspapers, 2000-2013. Journal of African American Studies, 20(3-4), 248-271. doi:10.1007/s12111-0169330-8

Yosso, T. J. (2005). Whose culture has capital? A critical race theory discussion of community cultural wealth. Race, Ethnicity and Education, 8(1), 69-91. 